\section{Slipchenko V., Poliagushko L., Kotunov V.}

\title{
DEVELOPMENT OF HARDWARE AND SOFTWARE OF THE COMPLEX FOR HYPOXYTHERAPY
}

Об’єктом дослідження є медичне апаратне і програмне забезпечення для проведення гіпокситерапї. Одним з найбільш проблемних місць є автоматизація оцінки стану гемодинаміки і системи дихання пацієнта під час сеансів.

У ході розробки комплексу для проведення гіпокситерапії використовувалися сучасні апаратні засоби (датчики кисню, вуглекислого газу, пульсоксиметрія тощо) і програмні методи фільтрацї сигналів. При розробиі програмного забезпечення для медперсоналу використовувалися сучасні засоби і технологї програмування (C\#, MySql, CLIPS).

Отримано принципово новий автоматизований програмно-апаратний комплекс, призначений для проведення діагностики та лікування пацієнтів. Це пов'язано з тим, що запропонований комплекс має ряд особливостей реалізацї основних його блоків. Зокрема автоматизоване робоче місце фахівия з гіпокситерапї $\epsilon$ Әинамічною експертною системою, що отримує дані з мікроконтролера в реальному часі під час сеансів, тому експертна оцінка робиться відразу ж. Система має повну базу знань для проведення оцінки сеансів діагностики і курсу процедур для пащієнтів, які вже мають розвинену гіпоксію (наприклад, при хронічній обструктивній хворобі легень) і без неї.

Завдяки иьому забезпечується:

- можливість отримання значень показників стану пачієнта (частота серцевих скорочень, сатурація крові, обсяг дихання, частота дихання, хвилинний обсяг дихання) та склад вдихаємої газової суміші (концентрація кисню і вуглекислого газу);

- надання експертної оцінки стану пацієнта.

У порівнянні з відомими гіпоксикаторами (Борей, AltiPower, CellAir One, ReOxy та інші) розроблений забезпечує такі переваги:

- проведення автоматизованої діагностики та оцінки ефективності курсу гіпокситерапї;

- малі габарити конструкцї для зручного використання навіть у домашніх умовах;

- невисока і доступна вартість комплексу для приватних і державних лікарень, поліклінік, медичних иентрів і спортивних комплексів.

Ключові слова: автоматизований програмно-апаратний комплекс, експертна система, діагностика стану пащієнта при проведенні гіпокситерапіі.

\section{Introduction}

Hypoxytherapy is one of the promising non-medicament methods of treatment and prevention of various diseases, which is based on respiration air with a reduced concentration of oxygen at normal atmospheric pressure [1]. The effectiveness of the use of hypoxytherapy in sports and medical practice has been proved by many years of research by leading experts in Ukraine, Australia [2], Germany, Russia, Belarus [3] and other countries to increase the body's resistance to negative environmental influences. For example, resistance to radiation, the treatment of respiratory diseases, cardiovascular system, circulatory system, allergic skin diseases, diabetes, chronic gynecological diseases, stimulation of the immunological defense system [4-6]. In connection with the great efficiency and wide range of application of the method, the sphere of development of devices and complexes for carrying out hypoxytherapy - hypoxicators is rapidly developing [7]. The analysis of existing devices and complexes showed that in most hypoxicators there is monitoring of the patient's condition, conducting diagnostics and analysis of the results of procedures, therefore the use of the method is limited.

Therefore, it is urgent to develop and study an automated software and hardware complex for carrying out hypoxytherapy, which makes it possible to diagnose the hemodynamic state and the patient's respiration system under the controlled delivery of a gas hypoxic mixture.

\section{The object of research and its technological audit}

The object of research is the designs and software of devices intended for carrying out hypoxytherapy.

Analysis of existing devices and complexes for carrying out hypoxytherapy (Table 1) [7-9] showed that the main task of all hypoxicators is the creation of a gas hypoxic mixture and feeding it to the patient. There are two approaches to creating a mixture: the respiratory one and the producer one.

The respiratory approach creates a gas mixture by rerespiration the patient, and the producer approach creates a gas mixture from the air using gas separation membranes. 
Analysis of hypoxicators

\begin{tabular}{|c|c|c|c|c|c|c|c|c|c|c|c|c|}
\hline Name & $\begin{array}{l}\text { Manu- } \\
\text { facturer } \\
\text { country }\end{array}$ & $\begin{array}{l}\text { Range } \\
\mathrm{D}_{2}, \%\end{array}$ & $\begin{array}{c}\text { Num- } \\
\text { ber of } \\
\text { patients }\end{array}$ & $\begin{array}{c}\text { Produc- } \\
\text { tivity, } \\
\text { 1/min }\end{array}$ & $\begin{array}{c}\text { Duration } \\
\text { of session, } \\
\text { min }\end{array}$ & $\begin{array}{l}\text { Method } \\
\text { of GM } \\
\text { creation }\end{array}$ & GM type & Power, W & $\begin{array}{c}\text { Dimensions, } \\
\text { cm }\end{array}$ & $\begin{array}{c}\text { Mass, } \\
\mathrm{kg}\end{array}$ & $\begin{array}{l}\text { Measu- } \\
\text { ring } \\
\text { parame- } \\
\text { ters }\end{array}$ & $\begin{array}{c}\text { Modes } \\
\text { of operation }\end{array}$ \\
\hline $\begin{array}{l}\text { Vershina, } \\
\text { Vershinka }\end{array}$ & $\begin{array}{l}\text { Moscow, } \\
\text { Russia }\end{array}$ & $10-21$ & 1 & - & 30 & Respiratory & $\begin{array}{c}\text { Hypoxic, } \\
\text { Hyperaxic }\end{array}$ & - & - & $\begin{array}{c}0.35 \\
0.7\end{array}$ & - & Treatment \\
\hline AltiPower & $\begin{array}{c}\text { Mel- } \\
\text { bourne, } \\
\text { Australia }\end{array}$ & $9-21$ & 1 & - & 30 & Respiratory & Hypoxic & - & $52 \times 38.5 \times 25.5$ & 4.7 & $\mathrm{O}_{2}$ & Treatment \\
\hline Hypotron & $\begin{array}{c}\text { Kyiv, } \\
\text { Ukraine }\end{array}$ & $8-17.5$ & 1 & 10 & 50 & Respiratory & Hypoxic & 25 & $\begin{array}{l}50 \times 18 \times 12.6 \\
22.5 \times 20 \times 13\end{array}$ & $\begin{array}{l}4.2 \\
2.0\end{array}$ & $\begin{array}{c}\mathrm{RF}, \mathrm{BV}, \\
\mathrm{MBV}, \mathrm{O}_{2}\end{array}$ & $\begin{array}{c}\text { Diagnostics, } \\
\text { Treatment }\end{array}$ \\
\hline ReOxy & $\begin{array}{l}\text { Luxem- } \\
\text { bourg; } \\
\text { Moscow, } \\
\text { Russia }\end{array}$ & $\begin{array}{l}10-14 \\
21,35\end{array}$ & 1 & 25 & $30-60$ & Producer & $\begin{array}{c}\text { Hypoxic, } \\
\text { Hyperoxic }\end{array}$ & 460 & $90 \times 60 \times 50$ & 38 & $\begin{array}{c}\mathrm{HB}, \\
\mathrm{SpO}_{2,} \\
\mathrm{O}_{2}, \mathrm{ND}_{2}\end{array}$ & $\begin{array}{c}\text { Diagnostics, } \\
\text { Treatment }\end{array}$ \\
\hline $\begin{array}{l}\text { CellAir } \\
\text { One }\end{array}$ & $\begin{array}{c}\text { Berlin, } \\
\text { Germany; } \\
\text { Moscow, } \\
\text { Russia }\end{array}$ & $\begin{array}{l}9-22, \\
36\end{array}$ & 1 & - & - & Producer & $\begin{array}{l}\text { Hypoxic, } \\
\text { Hyperaxic }\end{array}$ & 600 & $50 \times 53 \times 103$ & 18 & $\begin{array}{c}\mathrm{HB}, \\
5 \mathrm{pO}_{2}, \mathrm{O}_{2}\end{array}$ & Treatment \\
\hline $\begin{array}{c}\text { G02Al- } \\
\text { titude }{ }^{\circledR} \\
\text { Hypoxica- } \\
\text { tor system }\end{array}$ & $\begin{array}{c}\text { Mel- } \\
\text { bourne, } \\
\text { Australia }\end{array}$ & 9-15 & $\begin{array}{c}1,2,3 \\
4,5\end{array}$ & - & $45-60$ & Producer & Нypoxic & 1500 & $\begin{array}{l}27 \times 35 \times 10 \\
25 \times 100 \times 50\end{array}$ & $\begin{array}{c}\text { from } 7 \\
\text { to } 90\end{array}$ & $\mathrm{O}_{2}$ & Treatment \\
\hline BIO-NOVA & $\begin{array}{l}\text { Moscow, } \\
\text { Russia }\end{array}$ & $\begin{array}{c}10,12 \\
9-16\end{array}$ & $\begin{array}{l}1,2, \\
4,8\end{array}$ & - & 60 & Producer & Нypoxic & 800-1600 & - & $60-140$ & $\mathrm{O}_{2}$ & Treatment \\
\hline Нурохісо & $\begin{array}{c}\text { New York, } \\
\text { USA }\end{array}$ & $8-21$ & - & 120 & - & Producer & Hypoxic & - & $58.4 \times 39.4 \times 47$ & 26 & $\mathrm{O}_{2}$ & Treatment \\
\hline Borei & $\begin{array}{l}\text { Kyiv, } \\
\text { Ukraine }\end{array}$ & $10-16$ & $1-4$ & 40-170 & - & Producer & Нypoxic & - & $130 \times 60 \times 60$ & - & $\mathrm{O}_{2}$ & Treatment \\
\hline
\end{tabular}

Note: GM - gas mixture; $\mathrm{O}_{2}$ - oxygen; $\mathrm{NO}_{2}$ - nitrogen; $\mathrm{RF}$ - respiratory frequency; $\mathrm{BV}$ - respiratory volume; MRV - minute respiratory volume; $\mathrm{HR}$ - heart rate; $\mathrm{SpO}_{2}$ - blood saturation.

Constructions of respiratory type hypoxicators include a respiratory mask, a respiration bag, a cartridge with a carbon dioxide absorbent and regulators of hypoxia degree. The disadvantages of such hypoxicators is the need for a constant replacement of the carbon dioxide absorbent and disinfection of all components of the structure, and the advantages are small size, convenience at home and low cost. The simplified producer-type design consists of a compressor, a membrane unit, respiration tubes and a mask, and a control unit that controls the concentration of oxygen in the gas mixture and the oxygen sensor. Disadvantages of such structures are large dimensions and high cost, and the advantage is that it is not necessary to fully disinfect the device, but only the respiration tube and the mask through which the patient breathes.

Such designs ensure the operation of devices in the treatment mode and measurement of oxygen concentration in the inhaled mixture, but additional equipment must be used to diagnose the condition of patients during sessions. This makes it difficult to work and carry out the hypoxytherapy procedure.

\section{The aim and objectives of research}

The aim of research is development of hardware and software of the automated complex for hypoxytherapy with monitoring and diagnostic hemodynamic and respiratory system of the patient during the procedure and afterwards.
To achieve this aim, it is necessary to solve the problems:

1. To consider the components for constructing the hardware design of the complex, which create a gas hypoxic mixture and collects data on the patient's condition.

2. To develop software that allows to manage sessions and collect data.

3. To develop a workstation of hypoxytherapy specialist, which will provide an opportunity to view statistical information for all courses of patients and to assess the state of the patient's hemodynamic and respiratory system.

\section{Research of existing solutions of the problem}

Among the existing devices for carrying out hypoxytherapy (Table 1 [7-9]), hypoxicators «Hypotron» [10], ReOxy [11, 12] and CellAir One [13], which are equipped with additional sensors to determine the condition of the patient during the procedure.

The hypoxicator «Hypotron» refers to the respiratory type [14] and is equipped with a system for determining the change in airflow, which consists of a differential pressure sensor and a tube. With the help of this system, the parameters of human respiration (volume of respiration, respiratory rate, minute respiration volume) are calculated. This device can work autonomously or in conjunction with a personal computer. The doctor software allows to collect and save information about the patient's condition for further viewing, as well as conduct procedures 
in diagnostic mode, in which the concentration of oxygen gradually falls and the parameters of the person's respiration are fixed. Due to this, the optimal level of oxygen for comfortable and safe treatment is determined quickly in one session.

The «ReOxy» and «CellAir One» devices belong to the producer type [15] and are equipped with pulse oximeters for determining hemodynamic parameters (heart rate and oxygen concentration in the blood) during sessions. These devices work autonomously, without the possibility of connection to a personal computer, which makes it difficult to analyze the patient's condition in several sessions. The ReOxy software [16] allows to run the diagnostic mode, during which a hypoxic test is performed using a specially built-in technique. On the CellAir One device [17], the diagnosis is performed in the treatment mode with a stable concentration of oxygen according to the method determined by the physician.

Therefore, to date, there is no hypoxicator, in which the assessment of hemodynamics and the human respiratory system in the conduct of hypoxytherapy. Also in most epoxies there is no automated process for determining the optimal level of hypoxia for treatment sessions. The solution of these tasks is the main goal of the new development. When creating an automated software and hardware complex, a hypoxicator of the respiratory type «Hypotron» was chosen for the prototype. This device shows high reliability and safety during years of operation and has a low cost in comparison with producers of hypoxicators.

\section{Methods of research}

The development of an automated software and hardware complex for carrying out hypoxytherapy consists of the creation of hardware and software.

5.1. Hardware. The hardware implementation of the complex is shown on a schematic diagram (Fig. 1). The diagram shows the respiratory circuit, the control unit and the gas hypoxic mixture delivery system to the patient [18].

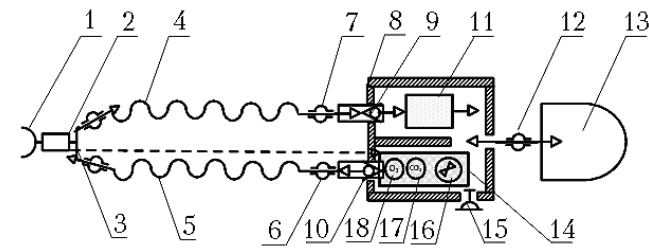

Fig. 1. Schematic diagram of the complex

During the hypoxytherapy, the patient breathes a gas hypoxic mixture that is in the respiratory chamber 8 and in the respiratory bag with a reservoir volume of 13 . The air exhaled by the patient passes through the respiratory mask 1, the differential pressure sensor 2, the Y-shaped connector 3, the respiration hose for exhalation 4, direct connector 7, exhalation valve 9 . After that, air enters the respiratory chamber 8 , namely into the receptacle with the carbon dioxide absorber 11 . Then the air enters the respiratory bag with the reservoir volume 13, created excessively e pressure inflates the bag. When the patient breathes in the gas hypoxic mixture, the return path passes through the second part of the respiratory chamber, which is connected to the control unit 14. The control unit consists of a fan 16, an excess pressure valve 15, carbon dioxide sensors 17 and oxygen 18, and a microcontroller, information from devices. Under the action of the vacuum, the inhalation valve 10 opens the air through the direct connector 6 , the respiratory hose for inspiration 5 , the $\mathrm{V}$-shaped connector 3, the differential pressure sensor 2 and the respiratory mask 1 enter the lungs of the patient.

The general block diagram of the system control unit is presented below (Fig. 2) [19].

The main part of the control unit is the microcontroller ATxmega32A4 (USA), which provides receiving of data from sensors, their mathematical processing and control of executive devices that maintain a predetermined concentration of gases in the inhaled gas hypoxic mixture. In addition, the microcontroller allows the device to communicate with a personal computer using the USB protocol.

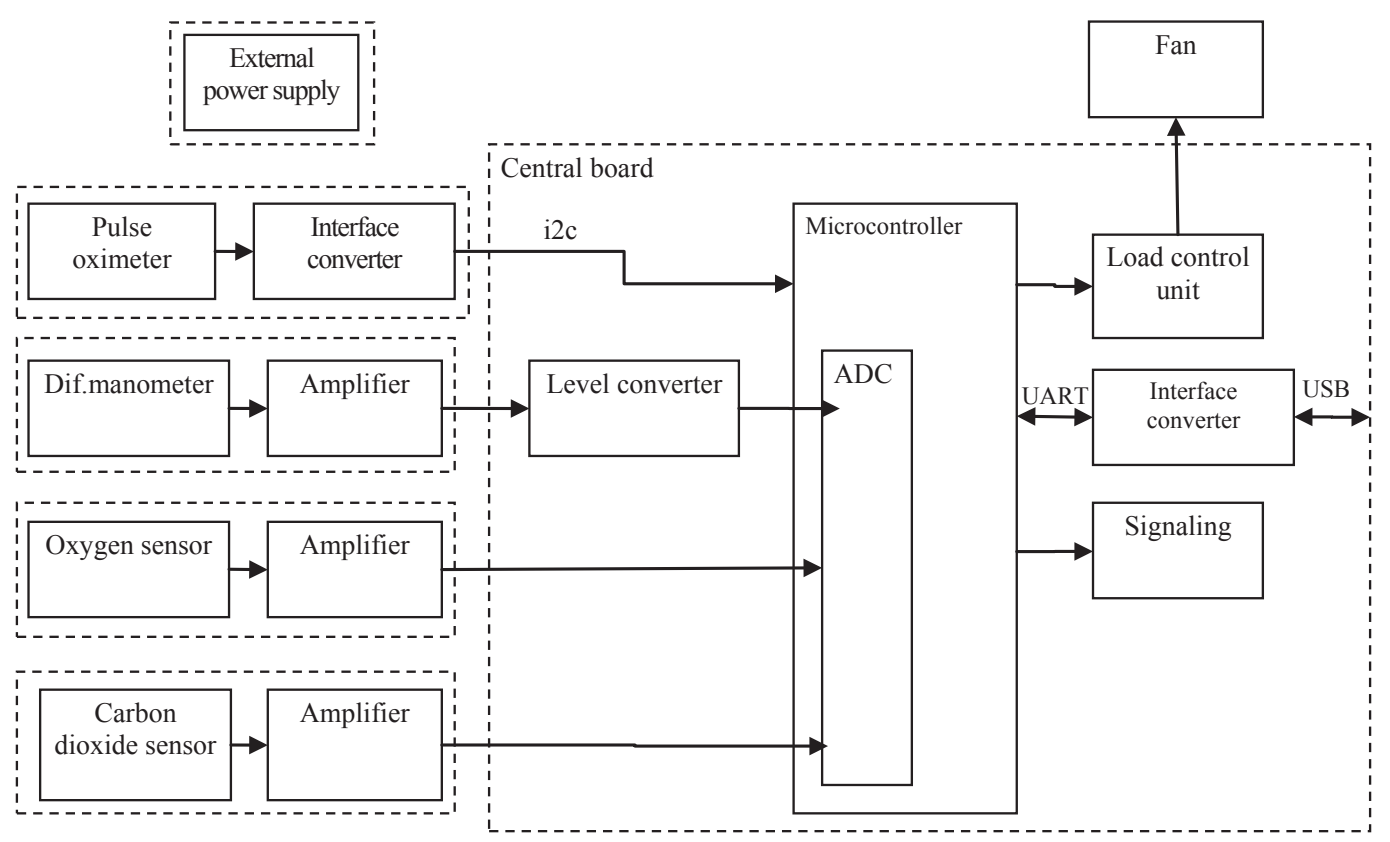

Fig. 2. Structural scheme: ADC - analog-to-digital converter; UART - Universal Asynchronous Receiver-Transmitter 
The patient's condition is monitored using a pulse oximeter module and an air flow measurement system. The composition of the inhaled gas hypoxic mixture is measured by oxygen and carbon dioxide concentration sensors.

Pulse oximeter is an independent measuring device, made in the form of a finger sensor and is designed to control the blood saturation and heart rate of the patient. The range of blood saturation measurements is $0-100 \%$, the heart rate is $30-250$ beats $/ \mathrm{min}$. Measured data is transmitted via cable to the main module via the i2c protocol.

Using a system that consists of a differential pressure sensor and a measuring tube, the flow rate of the inhaled and exhaled air is measured. The signal received from the sensor is amplified and filtered by hardware. Then it is fed to the analog-to-digital converter of the microcontroller, which performs software filtering, calculating the volume of inhalation/expiration and measuring the respiration rate. The way the differential pressure value is converted into a flow velocity depends on the design and parameters of the measuring element: tube or diaphragm. This system provides a measure of the volume of inspiration/expiration from $250 \mathrm{ml}$ to $6 l$ and respiration rate from 5 to $30 \mathrm{~min}^{-1}$. These limits are designed to discard false and noisy measurements and, if necessary, can be programmed by the user.

To determine the oxygen concentration, the electrochemical oxygen sensor KE-25 (Japan) is used, which creates an electromotive force directly proportional to the oxygen concentration in the air of the respiratory circuit. The signal from the sensor after amplification is fed to the input of the analog-digital converter of the microcontroller.

The sensor for the concentration of carbon dioxide is similar to the oxygen sensor, but contains a built-in electric heater. For a stable electrochemical reaction and correct measurements, the sensor should warm up before start of operation (5-7 minutes at room temperature). During warm-up, the sensor should be in an environment with a carbon dioxide concentration of not more than $0.04 \%$ (atmospheric air). The device determines the completion of warm-up and readiness for operation automatically, by analyzing the change in the electromotive force at the sensor output.

To maintain a predetermined oxygen concentration in the respiratory circuit, pumping of atmospheric air is provided by means of an integrated compressor. The rotation speed and operating time are calculated by the microcontroller, taking into account the difference between the specified and measured oxygen concentrations, as well as the rate of change in concentration.

To ensure the safety of the patient, the microcontroller constantly monitors the blood saturation and heart rate, and if the critical values are reached, the signaling sounds and the compressor switch to a constant supply of atmospheric air.

5.2. Software. The software implementation of the complex is divided into three programs: the service program for setting up the automated software and hardware complex, the software of the microcontroller and the automated workplace of the specialist in hypoxic training.

The service program for setting the operation of the complex performs such functions as: calibration of the oxygen sensor, installation of safety parameters and testing of the operation of the complex and all its parts.

Since the KE-25 electrochemical oxygen sensor is used in the complex to determine the oxygen concentration, in which the characteristic can change with time, the instrument provides calibration with atmospheric air $(20.9 \%$ oxygen) and recalculation of the proportionality coefficient. If after calibrating the calculated value of the proportionality factor is out of bounds - the user receives a message that it is necessary to replace the sensor.

To ensure the safety of health and the life of the patient during the hypoxytherapy sessions there is a constant monitoring of parameters: the concentration of oxygen, carbon dioxide, respiratory rate, respiratory volume, heart rate and blood saturation. When the parameters are exited, the signaling may be activated or the session may be stopped. Below are the critical parameter values (Table 2), which can be changed in the program.

Table 2

Critical security settings

\begin{tabular}{|l|c|c|}
\hline \multicolumn{1}{|c|}{ Options } & Signaling & Ending a Session \\
\hline Oxygen concentration & \multicolumn{2}{|c|}{ less $8 \%$} \\
\hline Carbon dioxide concentration & $0.8 \%$ & $1 \%$ \\
\hline Heart rate & $\begin{array}{l}\text { less } 50 \text { beats/min or } \\
\text { more } 110 \text { beats/min }\end{array}$ & $\begin{array}{l}\text { less } 40 \text { beats/min or } \\
\text { more } 140 \text { beats/min }\end{array}$ \\
\hline Blood saturation & $80 \%$ & $75 \%$ \\
\hline
\end{tabular}

The software of the microcontroller consists of several functional parts (Fig. 3).

The data received from the analog-to-digital converter are first processed by means of digital signal processing, in particular, filtration. According to the analog-digital converter, the concentration of gases in the respiratory mixture, the differential pressure in the measuring line of the volumetric air flow, the intensity of the photoplethysmogram signals and other service information are calculated. According to the volume flow rate, the volume and frequency of respiration are calculated. The photoplethysmogram is used for the analysis of heart rhythm and blood saturation. This information is processed to determine the patient's condition and, if necessary, to turn on the alarm or stop the procedure. Interaction with the doctor's personal computer and adjustment is carried out via the Modbus protocol. Multitasking and time synchronization is provided by a system of timers and interrupts.

The automated workplace of a specialist in hypoxic training is installed on the personal computer of the doctor, the software scheme of which is shown in Fig. 4.

The automated workplace of a specialist is a dynamic expert system. The system collects patient and session data from the microcontroller, which receives data from the sensors. The received data is stored in the local database. The display of information from the database and entered by the user is displayed in the user interface. The system assesses the diagnostic sessions and the effectiveness of the course of hypoxytherapy. The expert (a specialist in the field of hypoxytherapy) introduces new knowledge in the form of rules and facts that are stored in the knowledge base. Based on this, recommendations are given on further treatment or on the need for additional patient research and advice from other specialists. 


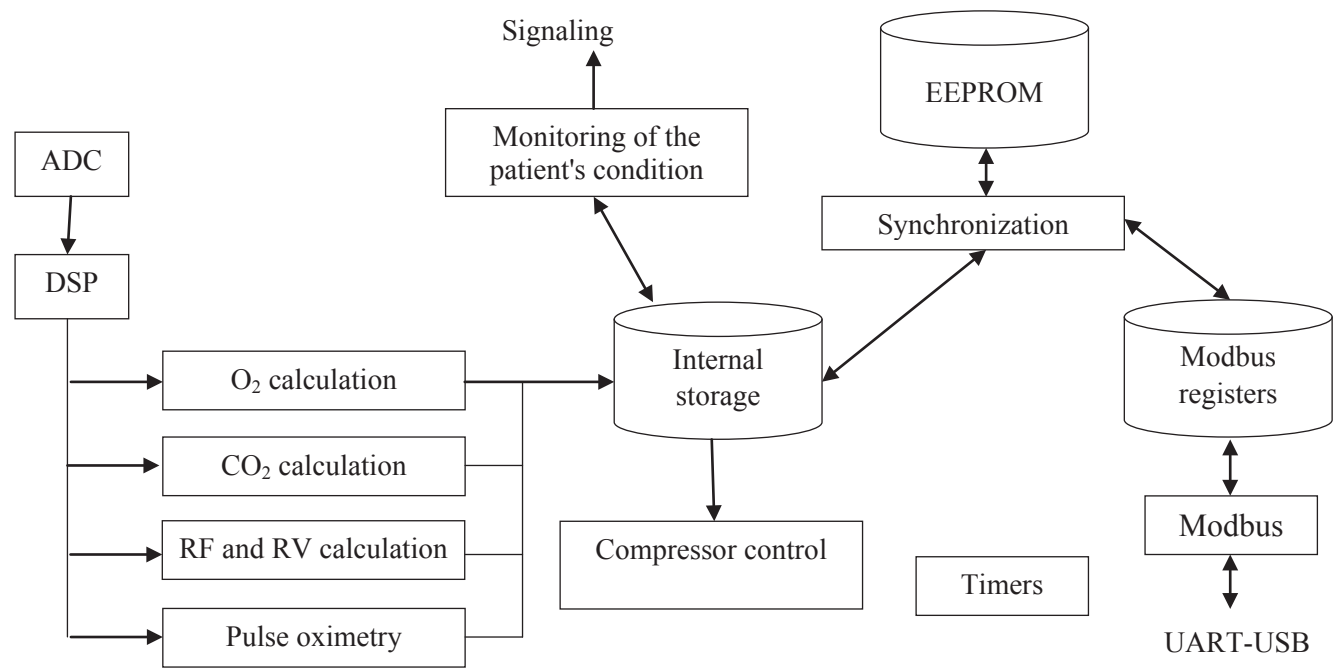

Fig. 3. Software of the microcontroller: ADC - analog-digital converter; DSP - digital signal processing; RF - respiratory frequency RV - respiratory volume; EEPROM - Electrically Erasable Programmable Read-Only Memory; UART-USB - Universal Asynchronous Receiver-Transmitter - Universal Serial Bus

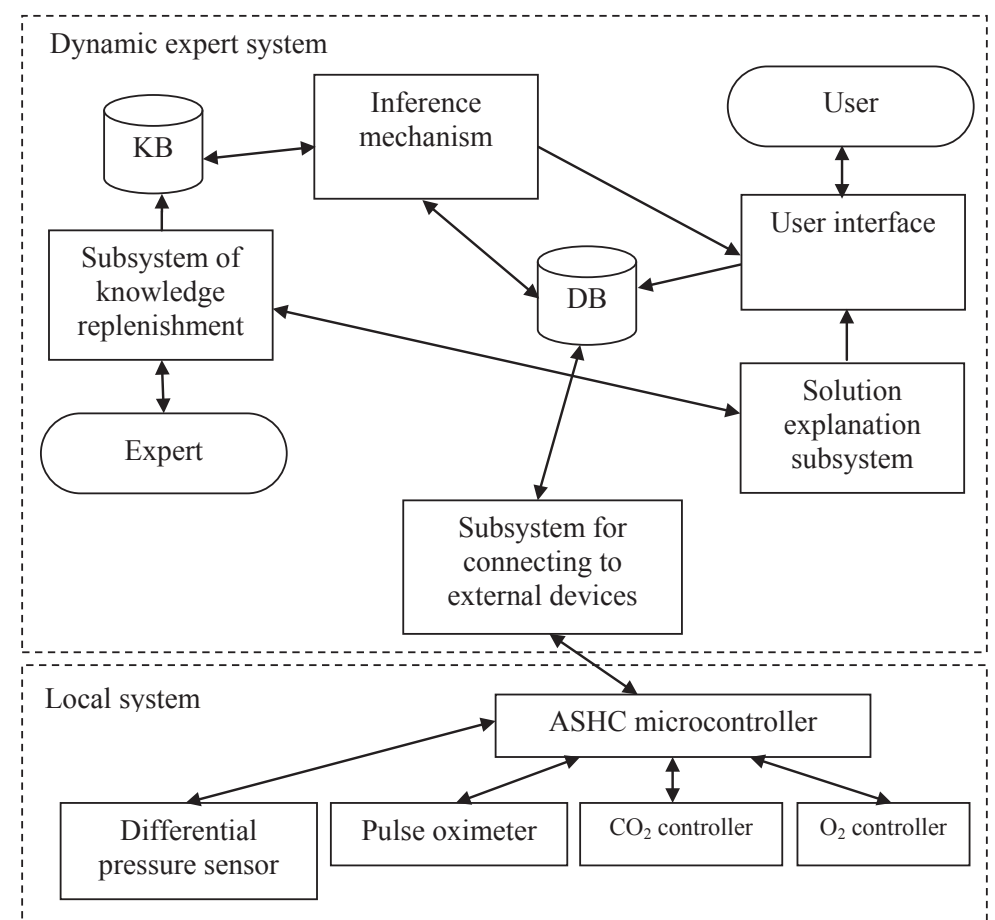

Fig. 4. General scheme of software on the personal computer of the doctor: KB - knowledge base; DB - database; ASHC - automated software and hardware complex

\section{Research results}

The appearance of the developed automated software and hardware complex is shown in Fig. 5.

The last version of the design of the automated software and hardware complex consists of three parts of the control unit, the respiratory chamber and the gas hypoxic mixture delivery system to the patient. Its special feature is the separation of the inspiratory and exhalation streams, which makes it possible to reduce the volume of dead space in the feed system of the mixture. This reduced the discrepancy between the oxygen concentration measured by the sensor and the oxygen concentration that reached the tubes before the patient with prolonged respiration. Fig. 6 shows the results of a patient's study in one of the available regimens (diagnosis or treatment) of conducting hypoxia sessions.

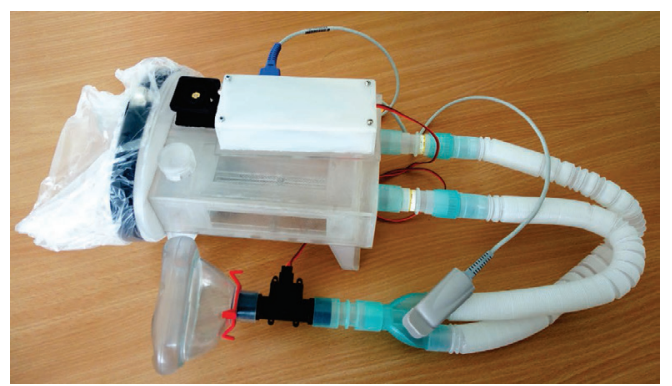

Fig. 5. Appearance of the developed automated software and hardware complex for carrying out hypoxytherapy 

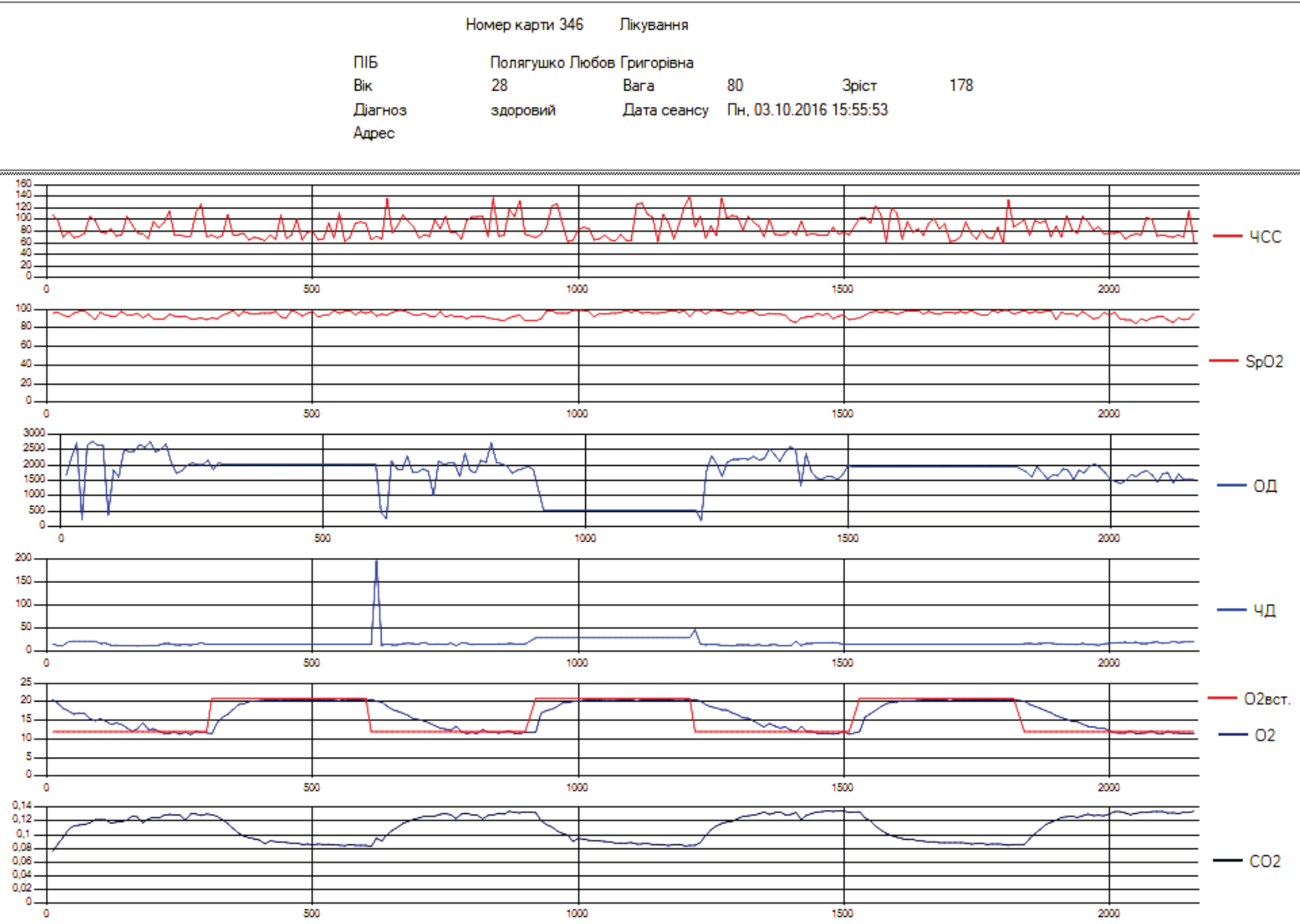

Fig. 6. Displaying the results of a hypoxytherapy session in the treatment regimen

Efficiency and effectiveness of the automated software and hardware complex is confirmed by:

- clinical research of Dmitry F. Chebotarev Institute of Gerontology of the National Academy of Medical Sciences of Ukraine;

- received methodological recommendations of the Ministry of Health «Application of interval normobaric hypoxic training in elderly patients with chronic obstructive pulmonary disease» No. 42.17/86.17 of April 21, 2017. The complex and methodical recommendations are recommended for introduction in the medical and preventive establishments of the Ministry of Health (regional, city and district) of the pulmonary and therapeutic profile.

\section{SWOT analysis of research results}

Strengths. The developed automated software and hardware complex for carrying out hypoxytherapy allows minimizing errors due to the human factor in diagnosing and assessing the patient's condition during sessions, and also makes the medical staff more conformable. The price of the complex in comparison with analogues, for example, CellAir One is 10 times cheaper. The compact dimensions of the complex make it possible to use it at home. The wide application of the method of hypoxytherapy in medical and sports practice, realized in this apparatus, allows using it in hospitals, polyclinics, medical centers, sports sections and in educational institutions.

Weaknesses. The weaknesses of the complex include the need for disinfection of the respiration circuit of the device after each patient, which leads to an increase in the necessary preparation time for the device. But this is solved due to the use of several sets of the respiratory chamber apparatus and the system of gas hypoxic mixture to the patient, which will reduce the time needed to prepare the device for patient-to-patient sessions.

Opportunities. The use of an automated software and hardware complex for carrying out hypoxytherapy at the enterprises will allow to reduce the costs for the payment of hospital costs by strengthening the immunity of employees and, as a consequence, to reduce their incidence. And also increase the stress-resistance, mental and physical performance of employees, which will increase the profit of the company through more efficient work.

Threats. When manufacturing this complex, quality foreign sensors are used, which are purchased in foreign currency, so the appreciation of the currencies will lead to an increase in the price in UAH.

\section{Conclusions}

1. The carried out analysis and research of components of existing hypoxicators allows to develop a fundamentally 
new automated software and hardware complex for carrying out hypoxytherapy. The constructions of the complex are optimal for the price of manufacture, the period of operation and a smaller payback in comparison with analogues. The constructions are given in patents No.113908 «Automated software and hardware complex «Hypotron-M», No. 115261 «Device for determining the resistance of the human body to hypoxia» and No.123682 «Automated software and hardware complex for carrying out hypoxic training».

2. The software for the microcontroller is developed, which allows processing signals from different types of sensors and devices (gas analyzers, pressure drop and pulse oximeter). According to the results of work, copyright was obtained for the computer program No. 75868 «System for accompanying interval normobaric hypoxic training».

3. An automated workplace for a specialist in hypoxic training is developed that minimizes errors due to the human factor in diagnosing and assessing the patient's condition during sessions. It also makes it possible to make the work of the medical staff more conformable with this complex. This development also received copyright for the computer program No.75870 «Automated workplace for a specialist in hypoxic training».

\section{References}

1. Hipoksiia yak metod pidvyshchennia adaptatsiinoi zdatnosti orhanizmu / Korkushko O. V. et al.; ed. by Korkushko O. V., Slipchenko V. H. Kyiv: NTUU «KPI», 2015. 482 p.

2. Regulation of Hypoxic Therapy and Altitude Training Devices in Australia. Australian Government. July 29, 2008. 33 p. URL: http://www.tga.gov.au/sites/default/files/consult-deviceshypoxic-080729.pdf

3. Nikolaeva A. G. Ispol'zovanie adaptatsii k gipoksii v meditsine i sporte: monograph. Vitebsk: VGMU, 2015. 150 p.

4. Intermittent hypoxia and human diseases / ed. by Xi L., Serebrovskaya T. V. London: Springer, 2012. doi:10.1007/978-1-4471-2906-6

5. Ishhuk V. A., Shatilo V. B. Izmenenie potrebleniya kisloroda pri standartnoy fizicheskoy nagruzke u lyudey pozhilogo vozrasta pod vliyaniem kursa interval'nykh normobaricheskikh gipoksicheskikh trenirovok: proceedings // Gipoksiya: mekhanizmy, adaptatsiya, korrektsiya. Moscow, 2005. P. 51.

6. Basovich S. N. Trends in the use of preconditioning to hypoxia for early prevention of future life diseases // BioScience Trends. 2013. Vol. 7, No. 1. P. 23-32. doi:10.5582/bst.2013.v7.1.23

7. Poliagushko L. H. Hipoksykatory ta yikh klasyfikatsiia // Hipoksiia yak metod pidvyshchennia adaptatsiinoi zdatnosti orhanizmu / ed. by Korkushko O. V., Slipchenko V. H. Kyiv: NTUU « KPI», 2015. P. 182-187.
8. Lopata V. A., Serebrovskaya T. V. Hypoxicators: review of the operating principles and constructions / ed. by $\mathrm{Xi} \mathrm{L}$. Serebrovskaya T. V. // Intermittent hypoxia and human diseases London: Springer, 2012. P. 291-302. doi:10.1007/978-14471-2906-6 24

9. Serebrovskaya T. V., Xi L. Intermittent hypoxia training as non-pharmacologic therapy for cardiovascular diseases: Practical analysis on methods and equipment // Experimental Biology and Medicine. 2016. Vol. 241, No. 15. P. 1708-1723. doi:10.1177/1535370216657614

10. Device for breathing hypoxic mixtures: Patent No. 74516 UA, MPK: A61M 16/00 / Slipchenko V. H., Shulzhenko O. F., Denysenko H. T. Published: 15.12.2005. Bul. No. 12.

11. Device for Complex Interval Normobaric Hypoxic-Hyperoxic Training of a Human: Patent No. 20090183738 US / Kostin A. I. et al. Published: 23.07.2009.

12. ReOxy. General description. URL: http://www.aimediq.com/ general-description.htm

13. CELLGYM Methode. URL: https://cellgym.de/

14. Nemerovskii L. I. Design of equipment for intermittent normobaric hypoxia // Biomedical Engineering. 1992. Vol. 26, No. 1. P. 1-5. doi:10.1007/bf00562631

15. Berestyuk G. I., Rozhanchuk V. N., Grishhenko V. I. Membrannoe gazorazdelenie v biologii i meditsine // Oroterapiya. Doklady akademii problem gipoksii. Vol. II. Kyiv, 1998. P. 13-18.

16. ReOxy 60-1001. Klinicheskoe rukovodstvo. Russia, 2013. 24 p.

17. HandBuch «CellAir One». Germany, 2016. 24 p.

18. Avtomatyzovanyi prohramno-aparatnyi kompleks dlia provedennia hipoksychnykh trenuvan: Patent No. 123682 UA / Kotunov V. O. et al. Published: 12.03.2018. Bul. No. 5.

19. Membrane technology as a basis for creation of treatmentand-prophylactic equipment for inhalation therapy and normobaric hypoxia / Rozhanchuk V. N. et al. // Fiziol Zh. 1992. Vol. 38. P. 91-94.

Slipchenko Volodymyr, Doctor of Technical Sciences, Professor, Department of Automation of Power Processes and Systems Engineering, National Technical University of Ukraine «Igor Sikorsky Kyiv Polytechnic Institute», Ukraine, ORCID: https://orcid.org/ 0000-0002-3405-0781

Poliagushko Liubov, Senior Lecturer, Department of Automation of Power Processes and Systems Engineering, National Technical University of Ukraine «Igor Sikorsky Kyiv Polytechnic Institute», Ukraine, ORCID: https://orcid.org/0000-0003-3287-8523

Kotunov Viacheslav, Postgraduate Student, Department of Automation of Power Processes and Systems Engineering, National Technical University of Ukraine «Igor Sikorsky Kyiv Polytechnic Institute», Ukraine, ORCID: https://orcid.org/0000-0002-9789-368X 